\title{
Employee Perceptions of the Effectiveness of Health and Safety Induction at ArcelorMittal, Vanderbijlpark, South Africa
}

\author{
Mothusi Samosamo \\ Post Graduate Candidate, Department of Human Resource Management, \\ Vaal University of Technology, South Africa \\ Email: samsam@exclusivemail.co.za \\ Christel Marais \\ Senior Lecturer, Department of Human Resource Management, \\ Vaal University of Technology, South Africa \\ Email: christel@vut.ac.za \\ Dr Pierre Joubert \\ Head of Department, Department of Human Resource Management, \\ Vaal University of Technology, South Africa \\ Email: pierrej@vut.ac.za
}

Doi:10.5901/mjss.2014.v5n23p412

\section{Abstract}

This study investigated the perceptions of employees of ArcelorMittal (Vanderbijlpark) regarding the effectiveness of health and safety induction they received. Simple random sampling was used within a quantitative research design to select 317 respondents out of 634 employees. Questionnaires were distributed within a demarcated division (Iron making division) and a total of 160 questionnaires were completed and returned. The collected data was statistically analysed and presented. The results indicated that the majority of employees perceive the health and safety induction they received to be effective. Respondents also indicated that ArcelorMittal was effective in providing them with the continuous support they need towards their health and safety. It is therefore recommended that the zero tolerance approach towards safety hazards be reinforced on a continuous bases within the work context of this leading steel manufacturer.

Keywords: employee induction, health and safety, employees' perceptions, work context.

\section{Introduction}

On an average each year, more than two million workers are killed and injured in work-related accidents globally (South Africa, 2007). This injury rate is increasing as employees are exposed to dangerous conditions within their working environments (Furter, 2003; Masia \& Pienaar, 2011). The Occupational Health and Safety Act 85 of 1993 (OHSA) (South Africa, 1993) highlights that every worker has a right to a healthy and safe working environment. Many expectations are built into this current legislation that specifies the responsibilities of employers and employees with regard to safe working practices. These suppositions are more likely to be fulfilled if an effective induction toward health and safety exists (Basson, Christianson, Garbers, Le Roux, Mischke \& Strydom, 2005).

The majority of injuries and fatalities are avoidable. Literature suggests that involving employees in the development and promotion of health and safety in the workplace reduces the levels of accidents and health related problems. Therefore, good and effective health and safety induction practices are to be observed. Poor induction and retention of relevant knowledge among employees are factors that lead to a high incidence of injury and deaths in the working environment (Mbana, 2005). Watson, Scott, Bishop and Tunbeaugh (2005) recommends that it would be of great value to the organisation and for the benefit of the workforce, to conduct a thorough review of induction practices and to make recommendations for enhanced health and safety delivery given that employees are the most important resources in an organisation.

A high frequency of injuries may be due to the lack of familiarity of recruits with the unique characteristics of a 
particular job, specific work environments, work methods, and the behaviour of co-workers (Saldana, Herrero, Del Campo \& Ritzel, 2003; DeCenzo \& Robbins, 2006). Health and safety performance is affected by an organisation's induction whereby employees are introduced and provided with information regarding their working environment (Grobler, Warnich, Carrel, Elbert \& Hatfield, 2011). Organisational induction is widely recognised as a key process to ensure that new employees are efficiently and effectively integrated within the organisation once they are recruited. Employee induction therefore has been identified as a critical factor that sets the tone for transmitting a state of familiarity towards the work environment and health and safety (Casio, 2006).

\section{Purpose of the Study}

The purpose of this study was to investigate the perceptions of employees of ArcelorMittal (Vanderbijpark) regarding the effectiveness of health and safety induction they received.

\section{Literature Review}

\subsection{The rationale for organisational induction}

Induction is crucial for employee's survival especially to cope with their working environment. The awareness of an environment helps them to adapt with ease, and to develop strategies for overcoming challenges within their working environment (Dube, 2008; Swanepoel, Erasmus, Van Wyk \& Schenk, 2008; Compton, Nankervis \& Morrissey, 2009). The basic information, when first introduced to an organisation, provides them with assistance to know what is expected of them (Redman \& Wilkinson, 2002; Gomez-Mejia, Balkin \& Cardy, 2004; Meyer, 2007).

There are several definitions for the term "induction". Swanepoel et al. (2008) argue that it is basically a structured process involving welcoming, receiving and introducing the newly appointed employees, providing them with the necessary information and making them feel at ease, so that they can settle down as soon as possible, and become productive at work. Similarly, Grobler et al. (2011) indicates that this process integrates the new employees into the organisation and briefs them about the details and requirements of the job. Robbins, Odendaal and Roodt (2009) also support the idea that the purpose of induction is to mould new employees through a formal or informal procedure that an employee goes through immediately after employment.

Organisations have their own induction practices-as per their needs and requirements (Kumar, 2011). This implies that there is no "set model" of induction. Therefore, through both formal and informal interactions and discussions each organisation is able to convey knowledge about its rules to new employees. Lawson (2002) and Harding (2008) indicate that new employees learn the organisational routine and underlying rules during the induction process. Indicators for successful integration into an organisation include organisational attachment and commitment, job satisfaction, social integration, role clarity, task mastery, values congruence, and perceived fit.

Among different induction procedures, the most essential aspect to be encountered if organisations wish its employees to survive and prosper in their new work environment is their health and safety (Rowley \& Jackson, 2011).

\subsection{Health and safety as a component of formal induction}

Health and safety have moved from only a concentration on injuries and accidents, and now emphasises the need to prevent people being harmed by work or becoming ill by providing a satisfactory working environment. Squelch (2001) argue that workplace operations should be carried out with the knowledge and awareness of the risks involved and how these risks can be minimised. Meyer and Kirsten (2005) indicate that health and safety induction should rest upon the fact that it provides employees with the basic understanding of their health and safety.

Squelch (2001) argues that organisations that undertake regular health and safety induction have better health and safety records and better-informed employees. However, the skills of employees would affect their responsiveness to health and safety therefore; varying training methods to health and safety could overcome this. Neale (2003) mentioned that prior to commencing work, each employee should receive health and safety induction training that will cover specific risks and location of hazards within the workplace.

A critical aspect of induction policy that relate to health and safety is aimed at providing new employees with relevant and pertinent information to acquaint them with the organisational goals and priorities, in order to enable their optimal functioning. The policy should be consistent with the Occupational Health and Safety Act (85 of 1993).

Legislation also provides the departure point for promoting and maintaining health and safety in the workplace. It 
imposes duties on employers to maintain, as far as reasonably practicable, safe working environments free from risks to the health and safety of employees (Labuschagne, 2001). It further obliges employees to take reasonable care and carry out all valid instructions in the interests of safety and to eliminate or control hazards or risks arising in the course of carrying out their work (Acutt \& Hatting, 2011). OSHA has traditionally emphasised controls and prescriptive regulations as solutions to the problem of reducing hazards in the workplace.

It is therefore argued that if the requirements of OHSA are applied and maintained, the risk and accidents in the workplace would be reduced (Swanepoel et al., 2008). Investigations into risks and accidents, however, indicate poor health and safety cultures (Taylor, 2010). A health and safety culture affects employee's perceptions, one of the key factors that influence safe and unsafe behaviour. Therefore, in order to better understand health and safety induction outcomes, within the context of this study, employees' perceptions have to be taken into account as safe or unsafe behaviour in the workplace is further influenced by perceptions (Flin, Conner \& Bryden, 2000; Jansen \& Brent, 2005; Che Hassan, Basha \& Wan Hanafi, 2007).

\subsection{Exploring the interaction between perception and resultant actions}

Perception allows actions to be planned prospectively and gears actions to the environment. Neal and Griffin (2002) indicates that perceptions of health and safety at work mediate related behaviours and outcomes. Mullins (2006) regards perception as the root of all organisational behaviour, and therefore employee perceptions on health and safety could vary depending on the priority it is assigned within the organisational context.

A strong impression about health and safety an employee has might lead them to dismiss any contrary evidence against their initial belief about health and safety. The attributions employees make for their own actions towards health and safety also influence their perceptions in the organisation. The different perceptions about the intertwining causal factors that lead to unsafe behaviours and other causes of accidents can create a chasm between actions and the perceived need for actions (Brown, Willis \& Prussia, 2003). For example, successful employees who succeed at tasks after completing an induction programme usually increase their confidence levels (DeJoy, Schaffer, Wilson, Vandenberg \& Butts, 2004). By understanding how employees perceive health and safety is vital within an organisation to recognise resultant actions of employees.

\section{Methods}

A questionnaire comprising of 7 sections was developed and distributed to the sample of 317 employees in the Iron making division of ArcelorMittal. The sections reflected on the following:

Section A: Employee exposure to health and safety induction programme.

Section B: Biographical information.

Section C: Employee experience of health and safety induction.

Section D: The effectiveness of health and safety induction.

Section E: Health and safety induction training as part of the induction programme.

Section F: Effectiveness of health and safety training.

Section G: Additional comments.

A 5-point Likert-type scale where " 5 " denotes strongly agree and "1" denotes strongly disagree was used to measure the responses of participants to the statements in the sections C, D, E, and F (Collins \& Hussey 2003). A total of 317 questionnaires were distributed and employees had an opportunity to complete the questionnaire on a voluntary basis during their own time. In total 160 questionnaires were returned, representing a response rate of 50\%. Neither the reasons for refusal to participate nor the characteristics of the non-respondents are known.

\section{Results and Discussions}

Table 1: Reliability analysis

\begin{tabular}{|ll|c|c|}
\hline \multicolumn{2}{|l|}{ Section } & Number of items & Cronbach alpha \\
\hline 1. & C (The employee induction) & 9 & .943 \\
\hline 2. & D (The effectiveness of employee induction) & 27 & .884 \\
\hline 3. & E (Health and safety induction training) & 15 & .976 \\
\hline 4. & F (The effectiveness of health and safety induction) & 18 & .976 \\
\hline
\end{tabular}


For the purpose of guaranteeing the maximum reliability of the scales proposed, Cronbach's a coefficient was calculated for sections C, D, E and F of the questionnaire as indicated in Table 1 above. The reliability study indicates the degree of internal consistency between the multiple variables that make up the scale, and represents the extent to which the indicators or items of the scale are measuring the same concepts. The Cronbach Alpha values for all the sections are above the threshold of 0.7 as suggested by Shiu, Hair, Bush and Ortinau (2009) indicating a high level of reliability.

An analysis of the results of section A indicate that all the respondents are working in the Iron making division and that they have all undergone health and safety induction. This qualifies them to participate in the study.

\subsection{Demographic profile of participants}

Section B of the survey collected demographic information and indicated that the study population consisted mainly of males $91.1 \%$. A total of $71.9 \%$ of the participants were black Africans. The mean age was 34 years (SD=10.969). Approximately $37.5 \%$ are Sesotho speaking as their home language. At least $33.8 \%$ hold Grade 12 as their highest qualification, $83.1 \%$ are permanent employees, $52.5 \%$ have been in their current position for 1-5 years and the same percentage have 1-5 years of their total period of service at ArcelorMittal. Approximately $25 \%$ work as artisans.

\subsection{Employee induction}

Table 2: Employee induction

\begin{tabular}{|c|c|c|c|c|c|c|c|}
\hline Code & Variables & 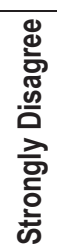 & $\begin{array}{l}\text { ঠু } \\
\text { ఫ্ঠু } \\
\stackrel{\leftrightarrow}{0}\end{array}$ & 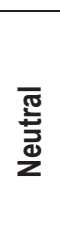 & ষ্ঠ & 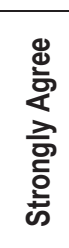 & 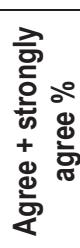 \\
\hline C1 & I am aware of the content of employee induction programme & & & 2.5 & 56.3 & 41.3 & 97.6 \\
\hline $\mathrm{C2}$ & I completed an induction programme upon my arrival at ArcelorMittal & & 0.6 & 0.6 & 45.6 & 53.1 & 98.7 \\
\hline C3 & I was informed about the date of the induction programme & & & 1.9 & 49.4 & 48.8 & 98.2 \\
\hline C4 & I was informed about the time of the induction programme & & & 1.9 & 51.9 & 46.3 & 98.2 \\
\hline C5 & I was informed about the venue of the induction programme & 0.6 & & 2.5 & 50.6 & 46.3 & 96.6 \\
\hline C6 & I was informed about the expected outcomes of the induction programme & 0.6 & 1.3 & 6.3 & 49.4 & 42.5 & 91.9 \\
\hline C7 & I was informed about the induction programme coordinator & & 1.3 & 5.6 & 55.6 & 37.5 & 93.1 \\
\hline C8 & I was informed about my role within an induction programme & & 0.6 & 6.3 & 51.3 & 41.9 & 93.2 \\
\hline $\mathrm{Cg}$ & $\begin{array}{l}\text { I was encouraged to complete the Induction Checklist at the end of the } \\
\text { induction programme }\end{array}$ & & & 3.1 & 52.5 & 44.4 & 96.9 \\
\hline
\end{tabular}

Table 2 reveal that the majority of respondents agreed and strongly agreed with all the statements. Therefore, for the purpose of the interpretation "agree" and "strongly agree" were combined. The critical outlook and reflection of the respondents on the employee induction led them to a realisation that their experience of the induction was very positive.

\subsection{The effectiveness of employee induction}

Table 3: Effectiveness of employee induction

\begin{tabular}{|c|c|c|c|c|c|c|}
\hline Code & Variables & 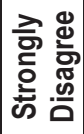 & 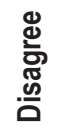 & 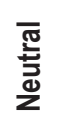 & 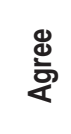 & 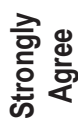 \\
\hline \multicolumn{7}{|c|}{ The first day: Initial induction } \\
\hline D1 & The induction I received helped me to become familiar with my new workplace & & & 1.3 & 48.8 & 50 \\
\hline D2 & The induction programme has helped me to do my current job more effectively & & & 1.3 & 53.1 & 45.6 \\
\hline D3 & I met my supervisor on the first day & & & 4.4 & 53.8 & 41.9 \\
\hline D4 & I was provided with the details of what is included in the employee induction programme & & & 3.1 & 55 & 41.9 \\
\hline D5 & I received an induction file covering induction objectives & 0.6 & 0.6 & 7.5 & 55.6 & 35.6 \\
\hline
\end{tabular}




\begin{tabular}{|c|c|c|c|c|c|c|}
\hline D6 & My induction partner (buddy) was indicated to me & 0.6 & 1.9 & 12.5 & 56.3 & 28.8 \\
\hline D7 & I was familiarised with my immediate work area & & & 5 & 60.6 & 34.4 \\
\hline D8 & I was introduced to colleagues I will be working with & & & 3.1 & 58.1 & 38.8 \\
\hline D9 & The duties of the job was discussed with me & & & 2.5 & 51.9 & 45.6 \\
\hline D10 & I was given a work area tour & & 1.9 & 1.9 & 53.8 & 42.5 \\
\hline D11 & I was given instructions on procedures to follow while doing my duties & & & 1.9 & 52.5 & 45.6 \\
\hline D12 & Health and safety procedures were explained to me & & & 1.9 & 48.8 & 49.4 \\
\hline D13 & I met with Induction Coordinator to review my progress & 0.6 & 0.6 & 7.5 & 50 & 40.6 \\
\hline \multicolumn{7}{|c|}{ Induction within the first week } \\
\hline D14 & My role within ArcelorMittal was discussed in detail with me & & & 3.8 & 56.9 & 39.4 \\
\hline D15 & Information about my division was provided to me & & 0.6 & 1.9 & 57.5 & 40 \\
\hline D16 & I met with my co-workers to discuss expectations of our working relationships & & & 3.1 & 56.3 & 40.6 \\
\hline D17 & $\begin{array}{l}\text { I was provided with the details about specific tasks I was required to perform in my } \\
\text { work context }\end{array}$ & & 0.6 & 1.3 & 53.8 & 44.4 \\
\hline D18 & $\begin{array}{l}\text { My facilitator provided me with continuous support while I adopted to my new } \\
\text { circumstances }\end{array}$ & & & 5.6 & 58.1 & 36.3 \\
\hline \multicolumn{7}{|c|}{ Induction during the first month } \\
\hline D19 & I gained an understanding of the rules and regulation relevant to my work & & & 0.6 & 52.5 & 46.9 \\
\hline D20 & My work progress was discussed with my immediate supervisor & & & 2.5 & 55 & 42.5 \\
\hline D21 & During the first month, I was provided with on-the-job training & & & 0.6 & 53.1 & 46.3 \\
\hline \multicolumn{7}{|c|}{ Induction within the first six months } \\
\hline D22 & Further training needs on the job was identified & & & 3.1 & 60 & 36.9 \\
\hline D23 & My supervisor scheduled meetings to discuss my performance appraisal & & 0.6 & 5 & 55 & 38.8 \\
\hline D24 & I was given constructive feedback on my job performance & 0.6 & & 3.8 & 56.9 & 38.8 \\
\hline D25 & I experienced the induction programme that I received as useful & 0.6 & & 1.9 & 53.8 & 43.8 \\
\hline D26 & $\begin{array}{l}\text { Induction programme effectively assisted me with my integration into the work } \\
\text { context }\end{array}$ & & & 3.8 & 53.1 & 43.1 \\
\hline D27 & $\begin{array}{l}\text { I felt that I am a part of ArcelorMittal after completing the employee induction } \\
\text { programme }\end{array}$ & & & 3.1 & 51.3 & 45.6 \\
\hline
\end{tabular}

The statistical analysis revealed in Table 3 indicates that the vast majority of respondents agreed and strongly agreed with all the statements in this section. Based on the statistical data, constant results were found through all induction stages. This indicates that respondents view the On-boarding programme (induction) as it was called at ArcelorMittal, as successful. This would imply that the majority of respondents feel that the employee induction was consistent and effective throughout all four stages.

\subsection{The health and safety induction training}

Table 4: Health and safety induction training

\begin{tabular}{|c|c|c|c|c|c|c|}
\hline Code & Variables & 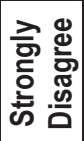 & 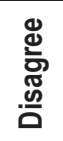 & $\begin{array}{l}\overline{\widetilde{\sigma}} \\
\text { 売 } \\
\text { z }\end{array}$ & 巡 & 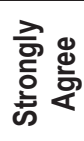 \\
\hline E1 & ArcelorMittal provided the health and safety induction training & & & 0.6 & 46.3 & 53.1 \\
\hline E2 & I was trained in health and safety procedures & & & 1.3 & 46.9 & 51.9 \\
\hline E3 & $\begin{array}{l}\text { Health and safety induction training ensured that I received effective information } \\
\text { about health and safety }\end{array}$ & & & 0.6 & 49.4 & 50 \\
\hline E4 & $\begin{array}{l}\text { Health and safety policies have been explained to me during the health and safety } \\
\text { induction training }\end{array}$ & & & 1.3 & 55 & 43.8 \\
\hline E5 & I was made aware of health \& safety practitioner in my department & & & 1.9 & 53.1 & 45 \\
\hline E6 & I was made aware of the occupational Health Service & & & 1.3 & 51.3 & 47.5 \\
\hline E7 & I was made aware of first aid box & & & 3.8 & 46.3 & 50 \\
\hline E8 & $\begin{array}{l}\text { The incident/accident reporting procedure was explained during health and safety } \\
\text { induction training }\end{array}$ & & & 0.6 & 47.5 & 51.9 \\
\hline E9 & $\begin{array}{l}\text { General workplace safety issues were discussed during the health and safety } \\
\text { induction training }\end{array}$ & & & 0.6 & 51.3 & 48.1 \\
\hline
\end{tabular}




\begin{tabular}{|c|c|c|c|c|}
\hline E10 & $\begin{array}{l}\text { Work with hazardous substances was explained during the health and safety } \\
\text { induction training }\end{array}$ & 0.6 & 50 & 49.4 \\
\hline E11 & $\begin{array}{l}\text { Safe use of machinery was discussed during the health and safety induction } \\
\text { training }\end{array}$ & 0.6 & 46.9 & 52.5 \\
\hline E12 & $\begin{array}{l}\text { Safe systems of work specific to my work context were clarified during the health } \\
\text { and safety induction training }\end{array}$ & 0.6 & 51.3 & 48.1 \\
\hline E13 & $\begin{array}{l}\text { The health and safety induction training informed me how to protect myself while I } \\
\text { perform my duties }\end{array}$ & 0.6 & 48.1 & 51.3 \\
\hline E14 & $\begin{array}{l}\text { The need for health and safety induction training was highlighted to me during the } \\
\text { health and safety induction }\end{array}$ & 0.6 & 50.6 & 48.8 \\
\hline E15 & Work activities that I am not permitted to undertake was clarified to me & 1.3 & 47.5 & 50.6 \\
\hline
\end{tabular}

The views of the respondents on the health and safety induction indicate that almost equal percentages of respondents agreed and strongly agreed with the statements (see Table 4). The majority of the respondents also believed that their health and safety induction was successful and therefore they were able to carry out their duties and responsibilities in a safe manner.

\subsection{The effectiveness of health and safety induction training}

Table 5: Effectiveness of health and safety induction training

\begin{tabular}{|c|c|c|c|c|c|c|}
\hline Code & Variables & 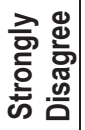 & 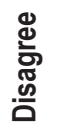 & $\begin{array}{l}\bar{\pi} \\
\text { 휸 } \\
\frac{0}{2}\end{array}$ & ষ্ঠ & 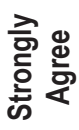 \\
\hline \multicolumn{7}{|c|}{ After completion of health and safety induction....... } \\
\hline F1 & I understand the Occupational Health and Safety Act & & & 0.6 & 48.8 & 50.6 \\
\hline F2 & I am aware of the location of the health and safety documentation & & & 0.6 & 50.6 & 48.8 \\
\hline F3 & I am familiar with the health and safety policies & & & & 48.8 & 51.3 \\
\hline F4 & I am able to use the equipment safely within my work context & & & & 49.4 & 50.6 \\
\hline F5 & I know how to communicate emergencies in my workplace & & & & 51.3 & 48.8 \\
\hline F6 & $\begin{array}{l}\text { I am aware of the safety measures that are taken to ensure that I am safe at the } \\
\text { workplace }\end{array}$ & & & & 53.1 & 46.9 \\
\hline F7 & I follow safety procedures & & & & 46.3 & 53.8 \\
\hline F8 & I know how to recognize safety hazards & & & & 49.4 & 50.6 \\
\hline F9 & $\begin{array}{l}\text { I have been made aware who the current Representatives on the Health \& Safety } \\
\text { Committee are }\end{array}$ & & & 2.5 & 47.5 & 50 \\
\hline F10 & I am able to seek positive improvements in my own health and safety environment & & & 0.6 & 50.6 & 48.8 \\
\hline F11 & I report anything that appears dangerous within the work environment & & & 0.6 & 45.6 & 53.8 \\
\hline F12 & I take reasonable care of myself in the work environment & & & & 45 & 55 \\
\hline F13 & I do not undertake tasks that I have not been trained to do & & & & 46.3 & 53.8 \\
\hline F14 & I follow the advice of safety notices & & & 0.6 & 46.3 & 53.1 \\
\hline F15 & I am working in a safe work environment & & & 1.3 & 45.6 & 53.1 \\
\hline F16 & ArcelorMittal as my employer is concerned with providing safe work environment & & & 1.9 & 48.8 & 49.4 \\
\hline F17 & Health and safety is a major concern at ArcelorMittal & & & 0.6 & 45.0 & 54.4 \\
\hline F18 & ArcelorMittal have done all that is reasonable to protect me in my workplace & & & 4.4 & 48.1 & 47.5 \\
\hline
\end{tabular}

Table 5 displays that the majority of the respondents believe that health and safety induction provided them with support they need to carry out their duties. Employees were afforded opportunities for health and safety induction and after completing their health and safety induction, they felt to have understood health and safety governing their work context and situations around them. Most importantly they felt they understood the Act regulating health and safety which will make them familiar with health and safety policies; safety procedures to follow; how to use equipment in a safe manner and any safety precautions that need to be taken care of when performing their work. ArcelorMittal upholds health and safety of its employees in the workplace as a priority. Respondents indicated that ArcelorMittal provides them with a safe work environment and has done all that is reasonable to protect them from any health and safety risks or hazards. 


\subsection{Factor analysis}

Factor Analysis was used to reduce the number of items in the questionnaire (Zikmund, Barbin, Carr \& Criffin, 2010) to those that best measure the constructs of section $\mathrm{E}$ (health and safety induction training) and section $\mathrm{F}$ (the effectiveness of health and safety induction). In addition factor analysis was used to detect the structure in relationships between these items.

Table 6: Factor analysis

\begin{tabular}{|c|c|c|c|c|c|c|}
\hline \multirow{2}{*}{ Sections } & \multicolumn{3}{|c|}{ Initial Eigen values } & \multicolumn{3}{c|}{ Extraction Sums of Squared Loadings } \\
\cline { 2 - 7 } & Total & \% of Variance & Cumulative \% & Total & \% of Variance & Cumulative \% \\
\hline E & 11.256 & 75.042 & 75.042 & 11.256 & 75.042 & 75.042 \\
\hline F & 12.843 & 71.352 & 71.352 & 12.843 & 71.352 & 71.352 \\
\hline
\end{tabular}

The results in Table 6 above indicates 75.042\% (15 questions) for section $\mathrm{E}$ and 71.352 (18 questions) for section $\mathrm{F}$ of the total variance among the items of each section in the questionnaire. Using the Principal Component Analysis as an extraction method, the results show that, all the questions in section $\mathrm{E}$ and $\mathrm{F}$ contribute to those sections.

Table 7: KMO and Bartlett's test

\begin{tabular}{|c|c|c|c|c|}
\hline & \multicolumn{2}{|c|}{ Kaiser-Meyer-Olkin test } & \multicolumn{2}{c|}{ Bartlett's test } \\
\hline Sections & Sampling adequacy & Approx. Chi-Square & df & Sig \\
\hline E & .908 & 3046.419 & 105 & .000 \\
\hline F & .926 & 3498.719 & 153 & .000 \\
\hline
\end{tabular}

A chi-square transformation of the matrix determinants was also undertaken to obtain a test statistic for Sphericity (Malhotra 2010:614). Table 7 above displays the approximate chi square of 3046.419 (section E) and 3498.179 (section F) with 105 (section E) and 153 (section F) degrees of freedom (df) which is significant (sig) at $p<0.000$ in both sections. The Kaiser-Meyer-Olkin measure of sampling adequacy (KMO) was 0.908 (section E) and 0.926 (section F) which was considered satisfactory for the use of factor analysis. The Bartlett's Test of Sphericity reached statistical significance $(p=<$ $.00)$, and in addition affirmed that factor analysis was appropriate for the data set.

\subsubsection{Independent t-test}

The T-Test was used to determine whether a statistical difference existed between males and females in relation to the effectiveness of employee induction (Section D). It was conducted with the Homogeneity value of 0.05 . The Homogeneity of Variance (Equal vs. Unequal) determines if there is a statistical significance at $5 \%$. The results were used to indicate which variables were significantly different between the two groups (Male and Female). Of the 27 questions, a statistical difference (sig. 2-tailed) was found on D11 (0.015), D17 (0.022), D19 (0.010), D20 (0.028), D21 (0.000), D22 (0.004), D25 (0.029), D26 (0.031), and D27 (0.019). The results indicated that male respondents felt stronger about the statements than their female counterparts.

\subsubsection{One-way analysis of variance.}

To avoid the problem of multiple T-Tests in a single-factor design, a one-way analysis of variance (ANOVA) was performed. This ANOVA explored the impact of the total period of service with the effectiveness of employee induction (Section B with Section D). A one-way analysis of variance was conducted where the test for Homogeneity of Variances was the Sig $>0.05$. The ANOVA looked for significant differences among the means by comparing the variances both within and between groups. The ANOVA results indicated only the items that differ from each other significantly in one or more characteristics, as the items that do not have statistical difference would not cause effect relationship of one or more characteristics.

Employees varying in total period of service differ significantly in the view of their familiarity with immediate work area (D7), the results indicate $0.045 \%$ of significance level. Employees differing in total period of service differ significantly in their views regarding the introduction to colleagues (D8), statistical data indicate $0.030 \%$ of statistical 
difference. Employees varying in the total period of service differ significantly in their views of how duties of the job were discussed $(0.043 \%)$. These imply that the extent to which duties were discussed differ in terms of the total period of service spent in that organization. Employees with varying total periods of service differ significantly in their views of the extent to which discussion on the expected working relationship was done with co-workers; the significant level was at $0.019 \%$.

\section{Empirical Findings}

The employee's perceptions were found to be positive overall. The majority of respondents indicated that they have received health and safety induction and felt that what they received as part of their induction programme as well as the implementation thereof was beneficial. It was also found that the majority of respondents believed health and safety induction provide them with the support they need to carry out their duties safely. Kwayiba (2009) confirmed that there is a strong relationship between employee's perceptions and health and safety in the workplace. This would imply that if employees perceive themselves to be empowered through the induction programmes implemented by ArcelorMittal, they were able to adhere to health and safety regulation.

\section{Limitations of the Study}

Although the objectives of the study were achieved, it was a once-off study. The results might be different if data is collected over time. The results of the study cannot be generalised to other sections of the company as data was only collected from the Iron making division.

\section{Recommendations for Future Research}

Limitations of this study confirmed the relevance of conducting further studies of other, more diversified populations. Some suggestions and directions for future research on the subject matter are discussed below.

- A comparative study including the other divisions of the company and other companies in the industry will add value to the results of this study.

- Future studies can also focus on a longitudinal study over an extended period as part of a continuous cycle of development to allow researchers to consider changes from same respondents over time.

- Consideration of a larger sample which will also be extended to contractors as they also undergo ArcelorMittal health and safety induction before executing any given duties might have revealed interesting findings.

\section{Recommendations for Management}

Continuous research is needed to develop an efficient health and safety induction tool and interventions designed to target factors that have an impact on the health and safety of employees. The findings will add value by assisting ArcelorMittal with the planning and developing of their health and safety induction to meet their goal of zero tolerance in safety hazards, and further identify their internal problems or deficiencies towards health and safety. This study may also assist ArceloMittal on how to eliminate injury and accident within their industry and act as a step towards achieving a safer work environment.

Employees of ArcelorMittal will benefit from the findings of this study, in that these findings will assist them with better understanding the concepts relating to health and safety as well as health and safety issues in their environment.

\section{Conclusion}

The purpose of the study was to determine the employee's perceptions of the effectiveness of health and safety induction. The results indicated that majority of employees are aware and have been exposed to health and safety induction which provided them with necessary information about health and safety. The study recommendations were highlighted. The finding reported in the study is expected to assist ArcelorMittal to develop an efficient health and safety induction tool to help eliminating injuries and accidents within the organisation, thereby enhancing the positive consequences of their employee induction programmes. 


\section{References}

Acutt, J., \& Hattingh, H. (2011). Occupational health: Management and practice for health practitioners. Cape Town: Juta.

Bakri, P., Zin, R. M., Misnan, M. S., \& Mohammed, A. H. (2006). Occupational Safety and Health (OHS) Management Systems: Towards development of safety and health culture. Proceedings of the $6^{\text {th }}$ Asia-Pacific Structural Engineering and Construction Conference, 5-6 September. Malaysia: Kuala Lumpur. [Online] Available: http://www.arcom.ac.uk/publications/procs/ar2007-0013-0022 (March 17, 2014)

Basson, A. C., Christianson, M. A., Garbers, C., Le Roux, P. A. K., Mischke, C., \& Strydom, E. M. L. (2005). Essentials of labour law: A new combined edition in one volume. (4th ed.). Cape Town: Creda Communication.

Brown, K. A., Willis, P. G., \& Prussia, G. E. (2003). Mental models of safety: Do managers and employees see eye to eye? Journal of Safety Research, 34(1), 43-156.

Casio, W. (2006). Managing human resources: Product, quality of work life, profits. (7th ed.). New York: McGraw Hill.

Che Hassan, C. R., Basha, O. J., \& Wan Hanafi, W. H. (2007). Perception of building construction workers towards health and safety and environment. Journal of Engineering Science and Technology, 2(3), 271-279.

Collins, J., \& Hussey, R. (2003). Business research: A practical guide for undergraduate and postgraduate students. (2nd ed.). Hampshire: Palgrave.

Compton, R., Nankervis, A., \& Morrissey, W. (2009). Effective recruitment and selection practices. (5th ed.). Australia: CCH Australia Limited.

DeCenzo, D. A., \& Robbins, S. P. (2006). Fundamentals of human resources management. (8th ed.). USA: John Willy \& Sons, INC.

DeJoy, D.M., Schaffer, B. S., Wilson, M. G., Vandenberg, R. J., \& Butts, M. M. (2004). Creating safer workplaces; Assessing the determinants and role of safety climate. Journal of Safety Research, 35(2), 81-90.

Dube, W. S. (2008). The induction of novice teachers in community junior secondary schools in Gaborone, Botswana. (MEdu Dissertation), University of South Africa, Pretoria, South Africa.

Flin, R., Conner, P. O., \& Bryden, R. (2000). Measuring safety climate: Identifying the common features. Safety Science, 34(1), 177-192.

Furter, E. (2003). Compliance and sustainable development. Safety Management, 3(1), 4-6.

Gomez-Mejia, L. R., Balkin, D. B., \& Cardy, R. L. (2004). Managing human resources. (4th ed.). New Jersey: Prentice Hall.

Grobler, P. A., Warnich, S., Carrel, M. R., Elbert, N. F., \& Hartfield, R. D. (2011). Human resource management in South Africa. (4th ed.). London: Cengage Learning.

Harding, A. (2008). Critical evaluation of induction in American Express. (MSc. Dissertation), University of Portsmouth, Chichester, England.

Jansen, J. C., \& Brent, A. C. (2005). Reducing accidents in the mining industry: An integrated

approach. The Journal of the South African Institute of Mining and Metallurgy, 105(3), 719-726.

Kumar, R. (2011). Human resource management: Strategic analysis, text and cases. New Delhi: I.K International Publishing House.

Kwayiba, T. F. (2009). Workers perception of occupational safety and health administration measures at Sasol Infrachem in Sasolburg. (MPhil. Dissertation), University of Fort Hare, East London, South Africa.

Labuschagne, P. W. (2001). A strategic management approach towards a comprehensive occupational health system. (MTech. Dissertation), University of Johannesburg, Johannesburg, South Africa.

Lawson, K. (2002). New employee orientation. USA: ASTD Press.

Malhotra, N. K. (2010). Marketing research: An applied orientation. (6th ed.). New Jersey: Pearson.

Masia, U., \& Pienaar, J. (2011). Unraveling safety compliance in the mining industry: examining the role of work stress, job insecurity, satisfaction and commitment as antecedents. SA Journal of Industrial Psychology, 37(1), 1-10.

Mbana, P. T. V. (2005). A social work study on the impact of legislation on the practice of employee assistance programmes in South African mining industry. (MTech. Dissertation), University of Pretoria, Pretoria, South Africa.

Meyer, M. (2007). Managing human resource development: Outcomes-based approach. (3rd ed.). Durban, South Africa: Butterworth.

Meyer, M., \& Kirsten, M. (2005). Introduction to human resources management. Cape Town: New Africa Education.

Mullins, L. J. (2006). Essentials of organisational behaviour. England: Prentice Hall.

Neal, A., \& Griffin, M. A. (2002). Safety climate and safety behavior. Australian Journal of Management, 27(1), 67-75.

Neale, R. H. (2003). Strategic management applied to international construction: Issue 7 of International Construction Management Series. Geneva: ILO Publications.

Redman, T., \& Wilkinson, A. (2002). The informed student guide to human resource management. London: Thomson.

Robbins, S. P., Odendaal, A., \& Roodt, G. (2009). Organisational behaviour: Global and Southern African perspectives. Cape Town: Pearson.

Rowley, C., \& Jackson, K. (2011). Human resource management: The key concepts. New York: Routledge.

Saldana, M. A. M., Herrero, S. G., Del Campo, S., \& Ritzel, D. O. (2003). Investigation of risks, accidents and injuries: Development of a report form and model. The International Electronic Journal of Health Education, 6(2), 47-60.

Shiu, E., Hair, J., Bush, R., \& Ortinau, D. (2009). Marketing research. (5th ed.). New York: McGraw Hill.

South Africa. (1993). Occupational Health and Safety Act 85 of 1993. Government Gazette, 442(36586).

South Africa. Department of Labour. (2007). The Labour Minister's speech at the International Occupational Health and Safety Day. (May 4). [Online]. Available: http://www.labour.gov.za/media/speeches.jsp?speechdisplay-id=12150 (March 17, 2014)

Squelch, A. P. (2001). Virtual reality for mine safety training in South Africa. The Journal of South African Institute of Mining and Metallurgy, 3(8), 209-216.

Swanepoel, B., Erasmus, B., Van Wyk, M., \& Schenk, H. (2008). South African human resource management: Theory and practice. (4th ed.). Lansdowne: Juta.

Taylor, J. B. (2010). Safety culture: Assessing and changing the behavior of organisation. England: Gower.

Vassie, L. H., \& Lucas, W. R. (2001). An assessment of health and safety management within working group in the UK Manufacturing sector. Journal of Safety Research, 32(1), 479- 490.

Watson, G. W., Scott. D., Bishop, J., \& Turnbeaugh, T. (2005). Dimensions of interpersonal relationships and safety in the steel industry. Journal of Business and Psychology, 19(3), 303- 318.

Zikmund, W. G., Babin, B. J., Carr, J. C., \& Griffin, M. (2010). Business research methods. (8th ed.). Manson: South Western Cengage Learning. 